TEME, г. XLIII, бр. 4, октобар - децембар 2019, стр. 1157-1169

Прегледни рад

https://doi.org/10.22190/TEME1910300690

Примљено: 30. 10. 2019.

UDK 343.14(497.11)

Ревидирана верзија: 10. 11. 2019.

Одобрено за штампу: 1. 12. 2019.

\title{
THE IMPORTANCE OF VOICE IDENTIFICATION IN THE WITNESS RECOGNITION PROCEDURE
}

\author{
Jadranka Otašević ${ }^{1 *}$, Saša Atanasov² \\ ${ }^{1}$ University of Belgrade, Faculty for Special Education and Rehabilitation, \\ Belgrade, Serbia \\ ${ }^{2}$ University of Priština temporary settled in Kosovska Mitrovica, \\ Faculty of Law, Kosovska Mitrovica, Serbia \\ jadrankastevovic@yahoo.com
}

\begin{abstract}
From a theoretical point of view, this paper considers the evidentiary action of recognizing the voice of the perpetrator by the witness. It is the identification of the voice by a person who is usually an "unprofessional listener". Due to the specificity of the voice as an object of recognition, the involvement of forensics (linguists and phoneticians) in the organization and immediate realization of the voice recognition action seems inevitable. Their activity would be manifested in giving guidance to the authority on how to increase the efficiency of voice identification and the accuracy of witness testimony. The witness gives evidence based on his perceptual (auditory) abilities in a procedure prescribed by the law, in which the credibility of his/her testimony is simultaneously checked and assessed. The Criminal Procedure Code of the Republic of Serbia establishes the legal framework for taking the voice recognition action, while the content of performing the direct recognition action is determined by the criminal-tactical rules.
\end{abstract}

Key words: voice, auditory presentation, procedural rules, criminal-tactical rules.

\section{ЗНАЧАЈ ИДЕНТИФИКАЦИЈЕ ГЛАСА У ПОСТУПКУ ПРЕПОЗНАВАЊА ЛИЦА ОД СТРАНЕ СВЕДОКА}

\footnotetext{
Апстракт

У раду се са теоријског аспекта разматра доказна радња препознавања гласа учиниоца кривичног дела од стране сведока. Реч је о идентификацији гласа од стране лица које је најчешће „непрофесионални слушалац”. Услед специфичности гласа као објекта препознавања, укљученост форензичара (лингвисте и фонетичара) у организацију и непосредну реализацију радње препознавања гласа чини се неизбежним. Њихова активност огледала би се у давању смерница органу поступка како да се повећа ефикасност идентификације гласа и тачности исказа сведока. Сведок даје исказ на основу перцептивних (слушних) способности у законом прописаном поступку у којем се истовремено проверава и оцењује веродостојност
} 
његовог исказа. Закоником о кривичном поступку Републике Србије утврђен је правни оквир предузимања радње препознавања гласа, док је садржина вршења непосредне радње препознавања одређена криминалистичко-тактичким правилима.

Кључне речи: глас, аудитивно предочавање, процесна правила, криминалистичко-тактичка правила.

\section{INTRODUCTION}

The need for identification is as old as humanity. At the beginning of the development of human civilization, the ability to recognize certain characteristics was the key to survival. In everyday life, we identify and recognize people around us by looking at and/or listening to them. Biological characteristics make each person a unique being on the planet (biological differences exist even in monozygotic twins). It is this uniqueness that underlies the identifying process, i.e. the identification (Tuthill,1994). The human voice is a feature that contains physiological and behavioral characteristics and is very specific. It is according to voice that people choose friends, partners and inadvertently create a picture of the speaker. It is an identity mark, because just as there are no two identical fingerprints, two identical manuscripts and two identical retinas, there are no two identical voices. In recent decades, there has been an increasing interest and need to identify perpetrators of crimes based on voice, as recognized by witnesses. The evidence they provide can be crucial to identifying the perpetrator, indicting him and ultimately convicting him. Therefore, it is absolutely necessary that the testimony of eyewitnesses is as accurate and complete as possible. In cases where there is no recording of the voice of the perpetrator, and the witness does not see the perpetrator but only hears their voice (for example: rape in the dark or with a mask on the perpetrator's face, robbery done by perpetrators wearing masks, etc.), the organ of the proceedings (which, depending on the phase of the proceeding, may be a public prosecutor, police or court) is compelled to take a voice recognition action to identify the perpetrator of the crime (voice line-up). The voice line-up is based on the same principles, defined by procedural and criminal rules, much in the form of the visual line-up. It is a complex identification procedure that establishes the identity of the voice presented with the voice previously heard. Auditory recognition can be organized, even if the voice recording of the perpetrator exists, as a supplement to expert analysis. This maximizes the use of all available information in a given case. The basic issue in case law, i.e. evidentiary proceedings, is the evidentiary value of auditory recognition (Hollien, 2012). Namely, it should be borne in mind that in voice identification procedures, recognition is most often performed by "nonprofessional listeners", and that identification is based on acoustic and linguistic features - information that carries the speech of the person to be identified (Schreuder, et al., 2018). Therefore, the involvement of forensic professionals (linguists, phoneticians) is required to help carry out the voice 
recognition work in an efficient and professional manner (Bojanić, et al., 2017). The basic requirement for taking and realizing a recognition action is the ability of the witness to accurately describe and subsequently recognize the characteristics of the perpetrator's voice. It essentially raises the question of the discriminating characteristics in the speech of two speakers and determining the criteria on the basis of which it can be determined with greater or less certainty whether there is a similarity between the speakers. No matter what methodological procedure is involved, recognition involves comparing a set of features and determining how similar or different the features are.

\section{ACOUSTIC AND PERCEPTIVE CHARACTERISTICS OF THE HUMAN VOICE}

The human vocal tract is a specific source of acoustic signal. It generates a signal (voice) that has speech-specific features. The frequency range of speech goes from $80 \mathrm{~Hz}$ to $12 \mathrm{kHz}$ and is the so-called speech frequency range. However, the most important is the frequency range between 250 and $5000 \mathrm{~Hz}$ in which speech intelligibility is $100 \%$ (Nešić, et al., 2011). The research work conducted in this area has shown that the frequencies of $500 \mathrm{~Hz}, 1 \mathrm{kHz}$ and $2 \mathrm{kHz}$ are the most important for a good understanding of speech. Vowels in the lower frequency range are known to provide the required power (loudness), and consonants, which are higher than vocals at higher frequencies, give intelligibility to speech. This indicates that the voice message is audible enough thanks to the vowels, and understandable thanks to the consonants. The average vowel power in speech is about 50W (in the case of a man's loud voice the power can reach the value of $2000 \mathrm{~W}$ ), the power of the quietest consonants is only 0.03W (Heđever, et al., 1997, p, 104 - 119). Therefore, although on average vowel power is about 1600 times greater than the power of the consonants, still the consonants are more important for speech intelligibility. This confirms that objective acoustic values do not always correlate with the subjective feeling. When it comes to speech communication, how we perceive voice or speech is equally important, along with the acoustic characteristics of the speech signal and its production (Musiek \& Chermak, 2007, p.78). We perceive our own speech through hearing and proprioception, and perceive the speech of the other person using our auditory and visual apparatus (in direct contact). In terms of perception, we can talk about three basic characteristics of sound. These are the intensity, pitch and color of the sound. The normal voice (speech) intensity of an individual in a quiet environment is between 60 and $65 \mathrm{db}$. The disturbing factors in speech perception and comprehension are: the distance between the speaker (sound source) and the listener, noise levels (interfering noise) and reverberation time (echo). 


\section{COMPLEXITY AND VARIATIONS OF SPEECH EXPRESSION}

People communicate using speech that is shared by their language community. However, this common language (speech) is at the same time the carrier of the individual characteristics of each speaker individually, in terms of spoken expression and in terms of the use of linguistic means. This individuality in the use of the common language can be used to confirm or deny one's identity on the basis of what has been said (uttered). Every communicative situation, even the short-lived one, reveals individual characteristics in both terms: in terms of speech expression, and in terms of the use of linguistic means at all levels of the linguistic structure. The appearance of personal speech characteristics and the personal style of using language means are major markers in determining the speaker's identity. The presence of context-induced variations in phonetic and linguistic terms in spoken expression is very important, as they form the basis of verbal expression. There are also variations of emotional nature. Other variations come to light depending on the conditions of conversation (speech in a noisy environment, in a hurry, in a café, etc.). Each feature in the speech signal has its own variation field or volume. This means that its variation can be caused by different factors controlling the organs of the articulation, and that the size of that field or volume depends on the physiological characteristics of the vocal tract. Thus, the basic frequency of the voice depends on the physiological characteristics of the vocal cords, on the psycho-emotional state, on the Lombard reflex when speaking in a noisy environment, etc. All this indicates that a good knowledge of the causes of detectable acoustic variations and their characteristics is a prerequisite for successful recognition of the speaker's speech (Јовичић \& Кашић, 2009). It should also be borne in mind that hearing-based testimony is generally less reliable than eye-witness testimony. The height, color and volume of sound and noise, its duration, and speech are audited and registered. Furthermore, the ability to adapt the sense of hearing, which is an individual characteristic of the listener, is very significant.

The hearing sense in situations where it is exposed to large noise, reflexively without the influence of willpower and consciousness, reduces its sensitivity, so that long-term exposure to large noise gradually diminishes its sensitivity. On the other hand, listening to noise and quiet tones directs attention, which increases the sensitivity of the hearing sense (Taylor, 2011). 


\section{AUDITIVE PRESENTATION (VOICE LINE-UP) - PROCESS AND CRIMINAL ASPECT}

\section{The Process Rules for Implementing a Voice Recognition Action}

Voice recognition action is a complex evidentiary action that legally determines the perpetrator's identity based on his or her voice. The Serbian legislature foresees the possibility of taking a voice recognition action throughout the proceedings, which is why we will use the term perpetrator for the person whose voice is to be recognized, which encompasses both the suspect when their voice is recognized in pre-trial or in the investigation, as well as the accused when recognizing is performed at the main trial.

The voice is recognized when the witness, who subsequently hears it, declares that he/she remembers the voice he/she has already heard and described (Marković, 1972, p. 437). The Criminal Procedure Code of the Republic of Serbia (Službeni glasnik Republike Srbije, 72/2011, 101/2011, 121/2012, 32/2013, 45/2013, 55/2014, 35/2019) in the provisions of Articles 100 and 90 provides for a voice as an object of the recognition action, but when determining the manner and conditions of performing the recognition action, it refers to the appropriate application of the provisions on taking the recognition action of a person or object.

The voice recognition action will be taken by the procedure authority when it is necessary to determine whether a witness recognizes a particular voice. The witness recognizes the voice by being presented, at the same time, with the perpetrator's voice, together with other voices unknown to them whose basic characteristics are similar to the voice described earlier by the witness. The presentation of voices is done by requiring the perpetrator and other persons to utter the same words or phrases in an identical manner (loud, quiet, or whispering) (Симоновић, 2004, стр. 269).

After the witness has been presented with a number of voices, he/she is required to say whether he/she recognizes any of them, and in the case of a positive (affirmative) response, to indicate to the recognized voice and to state whether they recognize the voice with certainty or with a certain degree of probability. There are, in fact, two degrees of belief - greater in the form of certainty and lesser in the form of a certain degree of probability. The degree of probability is expressed by witnesses as a percentage, seeking to more accurately express the degree of belief in their ability to accurately identify the voice of the perpetrator they have previously observed, taking into account the preponderance of the grounds in support of or at the expense of recognizing the voice (Илић и сар., 2013, стр. 288; Атанасов, 2016.). The outcome of the recognition action may consist of the correct or incorrect recognition of the voice. The correct outcome occurs when the witness recognizes the perpetrator's voice among multiple voices, or doesn't point to one of the voices presented when the perpetrator's voice is not present. The inaccurate outcome of the act of the recognition occurs when the witness 
misidentifies and points to a voice that is undoubtedly found to belong to a person other than the perpetrator (so-called false alarm), or when he/she fails to identify the perpetrator's voice by stating that he or she is unable to recognize the voice described previously, although the perpetrator's voice was among the voices presented (Kožar, et al., 2013, p. 251).

When a voice recognition action is taken in a pre-trial or during an investigation, it will be conducted in such a way that the person whose voice is being recognized cannot see or hear the witness, and in such a manner that the witness doing the identification cannot hear the perpetrator - the suspect, before the recognition procedure begins. The purpose of such an act of recognition is to protect the witness from any possible threat and harm that might occur by the person whose voice is being recognized, and at the same time to prevent the suggestive influence on the witness to identify a particular person by the voice heard just before the recognition action is taken, and not at the scene of the crime (Илић и сар., 2013, стр. 304). The identification action in the pre-trial procedure and in the investigation is carried out in the presence of the public prosecutor. The course of the proceedings and the results of the action taken should be recorded in minutes. Depending on how the voice recognition is implemented, various items (e.g. audio and/or video recordings) are an integral part of the record, which together with the content fixed in the record, represent a unity manifest the whole process of voice recognition action in an original way (Атанасов, 2014, стр. 228 - 240).

Unlike some foreign legal solutions, The Criminal Procedure Code of the Republic of Serbia regulates the manner of performing the recognition action. However, all questions related to the number of voices presented, the similarity of voices, taking the description of a voice, the moment when the authority takes the recognition action and other issues of importance for the effectiveness of the recognition action are left to criminal theory and practice.

\section{Criminal and Tactical Rules for Voice Recognition}

Recognizing the specificity of a voice as an object of recognition, criminal tactics have built a number of rules based on the facial recognition action, the proper application of which reduces the possible dangers of inaccurate recognition. Some of these rules are specifically mentioned as follows (Marković, 1972, p. 438 - 439):

- Prior to the immediate realization of the voice recognition action, it is necessary to determine the witness' ability to perceive the voice. This means that individual differences arising from the personality of the witness should be determined. First of all, the age of the witness should be determined (emotional sensitivity to other human senses is the first one that begins to weaken, which is why it is estimated that about $25 \%$ of the elderly have hearing impairment) (Simić et al., 2007, p. 82), the psychic personality of the witness (determining which type of observer the witness belongs to, auditory, visual, visual-motor or neutral), the witness' job (occupation) (musicians 
perfectly notice the differences between voices), cultural background (in theory, there is an understanding that people who are closer to the natural way of life have a better ability to perceive and observe sounds and voices), etc. (Marković, 1972, p. 438).

- The witness should be required to describe the conditions in which he/she observed the voice: where, when and under what circumstances he/she observed the voice. For example, where he/she stood and how far he/she was from the source of the voice, the perpetrator, because distance completely prevents or greatly reduces the ability to perceive, as well as to determine differential features (e.g., at the end of the $19^{\text {th }}$ century, one survey found that at 8 meter's distance from the speaker, $56 \%$ of listeners between the ages of 50 and 60 would hear whispers, $11 \%$ of them between the ages 60 and 70 and only $10 \%$ of listeners between the ages 70 and 80 . Persons older than 80 will be able to hear whispers only at a distance of 2 meters (about 40\%) (Smiljanić, 1999, p. 54). Furthermore, how long the speech and speech observation lasted (a short observation would make it impossible to perceive specific voice traits, that is, the length of the observation positively affects the accuracy of identification (Deffenbacher, 1991; In: Bornstein, 1995, p. 342); whether the observation was made outdoors or indoors (this significantly affects the content and scope of observations) (Marković, 1972, p. $438-$ 439); what were the weather and ambient conditions (e.g., whether it was raining and thundering, silent or noisy, whether other disturbing factors were present and which ones, because every aspect of the event that interferes with the perception of the perpetrator's voice has a negative impact on the later memory of the witness) (Deffenbacher, 1991 In: Bornstein, 1995, p. 342), whose voice he/she heard, what the characteristics of that voice are that make it specific to identify, whether he/she heard the whole speech or only part of it, etc. (Vodinelić et al, 1986, p. 241).

- It is crucial to determine the emotional state of the perpetrator at the moment when the witness observes his/her voice, because depending on the emotional state of the perpetrator, his/her voice also changes (Altavilla, p.322). For example, the voice of the perpetrator in anger or hatred can become squeaky, hoarse and metallic, and tremble in fear. The velvety voice of a woman in anger can become uncomfortable and stiff, while the voice of a man when addressing a beloved woman can get a feminine sweetness. The tone of the voice is also very important to determine, because depending on the tone of a single word or phrase, one speech may have different meaning (Altavilla, p.121).

- The interview with the witness should also include questions that determine the psycho-physical condition of the witness at the time the voice is observed, that is, whether he/she was rested or tired, intoxicated, whether his/her attention was focused on the voice to be recognized or whether he/she heard it suddenly and by chance, and whether the witness' memory of the acoustic contents is good or bad, and what the state of his hearing sense is, etc. (Vodinelić et al, 1986, p. 241). 
- It is necessary to require the witness to describe in detail the voice he or she will recognize, taking care not to ask questions that would suggestively affect the witness, and that the witness' ability to describe and recognize does not have to be developed to the same extent. Voice descriptions have value only if they indicate individual and, at the same time, differential features that make it possible to distinguish and recognize the voice (Marković, 1972, p. 439). In describing the voice, an effort should be made to determine the color, pitch and volume of the voice, determine whether the voice has been communicated in a whispered or altered voice, whether the voice has any particular characteristics and whether a specific characteristic is present in the mode of speech, in the mode of pronunciation of individual sounds, i.e., individual letters, especially the letter " $r$ ", what the speaker's accent is, whether the speech belongs to a particular dialect, slang, jargon, and the like (Pečjak, 1981, p. 458-459). Moreover, did he/she perceive the voice of a known or unknown person, because if the witness believes that they heard the voice of a known person, when he/she hears that voice again, the witness will not be able to correct that mistake.

- Due to the specific characteristics of the voice, experts (linguist and phoneticians) should be used during the first interview or examination of the witness. Reasons for this are to be found in the inability of most witnesses to describe the necessary characteristics of a voice suitable for its identification. Most witnesses perceive and remember the characteristics of the perpetrator's face and clothing better than the perpetrator's voice and speech, which is why the knowledge in the field of linguistics and phonetics related to the articulation and acoustic features of the voice and speech possessed by the linguist and phonetician will help the witness to accurately describe the voice that he/she has heard. If the authorities do not have the basic knowledge in this field, it is necessary to consult the experts mentioned above and to engage the linguist and phonetician in the course of drawing up voice and speech descriptions, selecting similar voices, and during the direct realization of the voice recognition action (Jokić, 2018, p.120).

- Voice recognition can be immediate and indirect in nature. Immediate voice recognition is performed with the witness listening to voices of persons in the adjacent room, while indirect recognition is realized with the witness' conclusion on the identity of the voice after hearing multiple recorded voices from the tape (Симоновић, 2004, стр. 269). Whether the recognition action will be taken directly or indirectly will depend on whether the perpetrator is cooperative and whether the perpetrator wants to participate in the recognition action, that is, whether the perpetrator is available to the authorities and whether there are recordings of the perpetrator's voice recorded by audio devices. Due to the need for auditory presentation to be carried out in a professional and efficient manner, a linguist should be involved in the organization process and the implementation of the voice recognition action. (Атанасов, 2016.; Bajin, 2010, p.301.). 
- The presented voices must be similar and the recognition must be of an optional character, i.e. the witness, among a number of similar voices, should point to a voice he/she has heard and described before. That is why the leader of the identification action should assemble a group of similar voices, which will be presented to the witness and which, by their characteristics, provide an adequate basis for identification.

- This means that the group of voices should be composed in a way that the voice of the perpetrator does not stand out by any means. Beside the suspect, the group consists of other persons (fillers), who are selected according to certain characteristics possessed by the perpetrator, for example, social affiliation and ethnicity, educational level, intensity, height and the color of the voice, etc. The spoken statement (pronouncement, content) should be the same as the one the witness originally heard at the time when the perpetrator uttered it. Some police agencies carry out this action by capturing the speech of each individual with special equipment (which must meet certain technical characteristics), and afterwards presenting them to the witness. Technical characteristics imply that the equipment can record and reproduce frequencies from 120 to $5500 \mathrm{~Hz}$, with an amplitude deviation not exceeding +/- 6dB. Other agencies find it more efficient to "perform a live presentation of the group." This is achieved by having a group of persons - voices of the presentation line - in a separate room from the witness listening behind the screen, or from the room next door (Stacey et all., 2018).

- The number of voices to be presented simultaneously will depend on the simultaneous capacity of the witness, which is an extremely individual matter. It is the witness' ability to receive a number of stimuli, which is the consequence of the selectivity of the sensory organs. Some psychologists believe that an adult should not be presented with more than six voices, and no less than three. Children, tired and frustrated witnesses, should not be presented with more than three voices; though there are different opinions (e.g. in England the number is at least 8, whereas in domestic literature the opinion is that this number should not exceed 8) (Aleksić \& Milovanović, 1993 , p. 215). With the increase in the number of stimuli, i.e. voices, attention becomes distracted, the witness cannot focus on the voices presented, and therefore, the result of the recognition taken may be incorrect (Vodinelić et al, 1986, p.242).

- Although it is indisputable in domestic theory and practice that the recognition action is performed by presenting multiple voices in order to identify them, and that there are no dilemmas about selective recognition, there are other opinions that highlight certain negative aspects of selective representation. Namely, the supporters of a different understanding emphasize the suggestive influence of the recognition action on the witness, i.e., they state that such recognition should be approached only when the witness declares that he/she remembers the voice heard during the critical event, and instead of presenting similar voices to the witness, different voices should be presented in order to be recognized by the witness. Vodinelić 
believes that these complaints are not justified and can be remedied by a number of appropriate measures. In the first place, he points out that the suggestive influence of the recognition action on the witness can be eliminated by removing the critical object of recognition - the voice will not be presented alone, but always with similar voices.

The Criminal Procedure Code prohibits asking suggestive questions during the interrogation of the witness, except at the main hearing when the witness is cross-examined, and consequently the creation of situations that would have a strong suggestive effect on the witness (e.g. giving only one voice to the witness for the sake of voice recognition) is prohibited (Vodinelić, 1985, p.575-576). Furthermore, leading a witness to hear the perpetrator before recognition is considered to be a suggestive act in the most dangerous way, and consequently no voice recognition action is allowed afterwards (Vodinelić et al, 1986, p. 241).

- Before the act of recognizing the voice, the witness must be asked a specially formulated question for this action: "Is there among the presented voices the voice you described earlier, or is that not the case?" (Vodinelić, 1996, p. 232), which will lift off the burden of the witness to necessarily label one of the voices as the voice that he/she heard at the critical moment. However, according to some psychologists who have dealt with the range of recognized material, if the voices are very similar in perceptual characteristics, the recognition success may be "somewhat better than accidental guessing" (Pečjak, 1981, p. 263).

\section{CONCLUSION}

Voice recognition action is a complex evidentiary action taken by the authority when it is necessary to determine whether the witness recognizes a voice heard earlier. When the witness has not seen the perpetrator but only heard his/her voice, the organ of the proceeding will take a voice recognition action, the result of which is evidence that can be used in the perpetrator's guilty plea and upon which a verdict can be based and reached. The perpetrator's voice is characterized by color, volume, strength and speed, i.e. a series of individual characteristics that make each individual's voice, regardless of the variations expressed, suitable for identification. Some of these characteristics are natural features, determined by hereditary and physiological factors, and some are acquired habits. Voice recognition is a complex evidentiary action. The completion of this action requires the proper implementation of legal provisions and criminal-tactical rules (especially those concerning the number of voices to be presented to the witness, meeting the criteria of the similarity of voices, eliminating suggestiveness, protecting witnesses, using phoneticians, linguists, etc.). Principally, it should be borne in mind that voice-based perpetrator identification is most commonly performed by "non-professional listeners", which is why the 
participation of phoneticians, i.e. linguists, represent the conditio sine qua non (a necessary condition) of the effective realization of the voice recognition action.

\section{REFERENCES}

Aleksić, Ž.; Milovanović, Z. (1993). Leksikon kriminalistike [Criminalistics Lexicon], Beograd: Vrelo.

Altavilla, E. (1955). Psicologia giudiziaria. Unione tipografico-editrice Torinese.

Atanasov, S. (2014). Prepoznavanje lica od strane svedoka, [Witness recognition]. U Zoran Isailiović (ur.): Naučno istraživački projekat „Zakonodavstvo Republike Srbije - stanje, ciljevi i dalji razvoj za period 2013-2015, 2, str. 228-240. Kosovska Mitrovica : Pravni fakultet Univerziteta u Prištini sa privremenim sedištem u Kosovskoj Mitrovici.

Atanasov, S. (2016). Uloga svedoka u otkrivanju i dokazivanju krivičnog dela. [The role of witnesses in detecting and proving a crime], Kosovska Mitrovica: Pravni fakultet Univerziteta u Prištini sa privremenim sedištem u Kosovskoj Mitrovici (doktorska disertacija).

Bajin, M. (2010). Uloga lingviste u kreiranju auditivnog predočavanja [The role of the linguist in creating the auditory presentation], U Željko Nikač (ur.): Pravo i forenzika u kriminalistici, 2 (str. 301). Beograd: Kriminalističko-policijska akademija.

Bojanić, N., Bajraktarević-Pajević, D. (2017). Uvođenje sistema kontrole kvaliteta kriminalističkih vještačenja u Bosni i Hercegovini, Bezbednost. [Implementation of a quality control system for criminal expert witnesses in Bosnia and Herzegovina], 59(1), 78-98. doi:10.5937/bezbednost1701078B

Bornstein, B. H. (1995). Memory processes in elderly eyewitnesses: What we know and what we don't know. Behavioral Sciences \& the Law, 13(3), 337-348. doi.org/10.1002/bsl.2370130303

Heđever, M. (2009). Uvod u forenzičnu fonetiku i akustiku. [Introduction to forensic phonetics and acoustics], Skripta iz kolegija forenzična fonetika i akustika. Zagreb: Edukacijsko rehabilitacijski fakultet.

Hollien, H. (2012). On earwitness lineups. Investigative Sciences Journal, 4(1), 1-17.

Ilić , P. G., Majić, M., Beljanski, S., Trešnjev, A. (2013). Komentar Zakonika o krivičnom postupku. [Comments of the Code of Criminal Procedure], Beograd: Službeni glasnik, Republike Srbije.

Jokić, D. (2018). Prepoznavanje lica na osnovu glasa - oblici, ograničenja i pravila. [Voice based recognition - Forms, constraints and rules], Revija za kriminologiju i krivično pravo, 56 (1), 115-126.

Jovičić, S., Kašić, Z. (2009). Intra-spikerske varijacije u govoru: forenzičke implikacije, [Intra-Speaker Variations in Speech: Forensic Implications]. U: Internacionalna Konferencija primenjene lingvistike, Novi Sad.

Kožar, D., Vukosav, J., Zarevski, P. (2013). Psihološki i organizacijski aspekti prepoznavanja osoba u liniji za prepoznavanje [Psychological and organizational aspects of recognizing persons in the line of recognition], Policijska sigurnost, 22 (2), 248-258.

Marković, T. (1972). Suvremena tehnika istraživanja krivičnih djela (kriminalistika) [Modern crime research technique, Criminalistic]. Zagreb: Narodne novine.

Musiek, F. E., \& Chermak, G. D. (Eds.). (2013). Handbook of central auditory processing disorder, volume I: Auditory neuroscience and diagnosis (Vol. 1). Plural Publishing. 
Nešić, L, Kovačević, J., Stevović-Otašević, J. (2011). Forenzička analiza govornog signala, [Forensic analysis of speech signal], Pravni život, 60 (5-6), 87-102.

Pečjak, V. (1981). Psihologija saznavanja. [The psychology of cognition], Sarajevo: Svetlost, I izdanje.

Schreuder, M. J., Meyer, T., \& Krix, A. C. (2018). Frightened by the perpetrator's voice: Startle responsivity and cognitive processing predict earwitness speaker identification. Biological psychology, 134, 80-88. doi: 10.1016/j.biopsycho. 2018.02.013.

Simić, S., Milovanović, S., Barišić, J., Crnobarić, C., Šikanić, N., Bajić, G. (2007). Starenje i psihološke promene.[Aging and psychological change],. Engrami, 29 $(3,4), 77-85$.

Simeunović, B. (2004). Kriminalistika. [Criminalistics], Kragujevac: Pravni fakultet u Kragujevcu.

Smiljanić, V. (1999). Razvojna psihologija. [Developmental psychology], Beograd (Belgrade): Centar za primenjenu psihologiju Društva psihologa Srbije.

Stacey, P., Dunn, A., Smith, H., Robson, J., \& Baguley, T. (2018). Forensic voice discrimination: The effect of speech type and background noise on performance.

Taylor, G. (2011). Jury trial in Austria. New Criminal Law Review: In International and Interdisciplinary Journal, 14(2), 281-325. doi:10.1525/nclr.2011.14.2.281

Tuthill, H. (1994). Individualization: Principles and procedures in criminalistics. Salem, OR: Lightning Powder Company.

Vodinelić, V. (1985). Kriminalistika, otkrivanje i dokazivanje. [Criminalistic, detection and proving], Skopje: Fakultet za bezbednost i opštestvena samozaštita.

Vodinelić, V., Cerovac, V., Jelačić, O., Baričević, J., Pavišić, B., Bukljaš, Z. \& Nikolić, Ž.(1986). Saobraćajna kriminalistika, Metodika obrade saobraćajnih nesreća na putevima, vodi i vazduhu. [Traffic Criminal Investigation, Methods of handling traffic accidents on roads, water and air. Witness recognition], Beograd: Savremena administracija.

Vodinelić, V. (1986). Kriminalistika. [Criminalistic], Beograd: Zavod za udžbenike i nastavna sredstva.

Zakonik o krivičnom postupku, Sl. glasnik RS, 72/2011, 101/2011, 121/2012, 32/2013, 45/2013, 55/2014, 35/2019.

\title{
ЗНАЧАЈ ИДЕНТИФИКАЦИЈЕ ГЛАСА У ПОСТУПКУ ПРЕПОЗНАВАЊА ЛИЦА ОД СТРАНЕ СВЕДОКА
}

\author{
Јадранка Оташевић ${ }^{1}$, Саша Атанасов ${ }^{2}$ \\ ${ }^{1}$ Универзитет у Београду, Факултет за специјалну едукацију и рехабилитацију, \\ Београд, Србија \\ ${ }^{2}$ Универзитет у Приштини са привременим седиштем у Косовској Митровици \\ Правни факултет, Косовска Митровица, Србија
}

\section{Резиме}

Радња препознавања гласа је сложена доказна радња коју орган поступка предузима када је потребно утврдити да ли сведок препознаје глас који је раније чуо. Када сведок није видео учиниоца кривичног дела, већ је само чуо његов глас, орган поступка ће предузети радњу препознавања гласа, чији резултат представља доказ који се може користити у поступку доказивања кривице учиниоца кривичног дела и 
на коме се може заснивати судска пресуда. Радња препознавања гласа може се предузети током целог поступка, с тим да је орган поступка дужан да појачане мере заштите сведока примени када се ова радња предузима у предистражном поступку и истрази. Глас учиниоца кривичног дела карактерише боја, јачина, снага и брзина, односно низ индивидуалних карактеристика које глас сваког појединца, независно од изражених варијација, чини погодним за идентификацију. Нека од наведених обележја природна су датост коју одређују наследни и физиолошки фактори, а нека стечених навика, услед чега не постоје два иста гласа, као што не постоје два иста отиска или две исте мрежњаче. Стога је могуће на основу гласа посредно сазнати и о више других карактеристика учиниоца кривичног дела, које су оријентационог карактера, као што су: старост и пол говорника, здравствено стање. Радња препознавања гласа представља сложену доказну радњу за чију реализацију је непходна правилна примена законских одредаба и криминалистичко-тактичких правила (нарочито оних која се тичу броја гласова који ће бити предочени сведоку, испуњења критеријума сличности гласова, отклањања сугестивности, заштите сведока, коришћења фонетичара, лингвиста и др.). Треба имати на уму да идентификацију учиниоца кривичног дела на основу гласа врше најчешће „непрофесионални слушаоци”, због чега учешће фонетичара, тј. лингвисте, представља conditio sine qua non ефикасне реализације радње препознавања гласа. Њихово учешће чини се нарочито важним у моменту када сведок врши опис гласа који је чуо, током формирања групе гласова који ће бити предочени сведоку, као и током непосредне реализације радње препознавања. 